\title{
Comparison of Weight, Components and Chemical Composition of Eggs in Guinea Fowl, Turkey, and Domestic Chicken
}

\author{
Shahrazad M.J. Al-Shadeedi \\ College of Veterinary Medicine, University of Baghdad, Baghdad, Iraq \\ Corresponding author’s Email: shahrazad@ mracpc.uobaghdad.edu.iq ; ORCID: 0000-0003-1706-8928
}

Received: 29 Nov. 2019

Accepted: 28 Jan. 2020

\begin{abstract}
The present study was carried out to compare the physicochemical characteristics of eggs of guinea fowl, turkeys and domestic chickens outdoor reared in traditional farms in Baghdad, Iraq. A total of 166 fresh eggs; 32 eggs from guinea fowls (Numida meleagris), 44 eggs from turkeys (Meleagris gallopavo) and 90 eggs from domestic chickens; were collected. Egg weight, percentage of egg components, chemical composition (protein, lipids, and ash), and lipid profile were determined. Results revealed the significant differences in egg weight among studied birds. The average egg weights for guinea fowl, turkey, and indigenous chicken were 83.15 $\pm 0.72,92.41 \pm 0.78$ and $61.28 \pm 0.62 \mathrm{~g}$, respectively. No significant differences were found in egg components and the chemical composition of the edible portions of the eggs among studied birds. However, the lipid profile of egg yolk indicated that egg cholesterol and LDL levels were significantly higher in guinea fowl and turkey compared with those in indigenous chickens, whereas native chicken has high values of HDL compared to guinea fowl and turkey. There were no significant differences in the triglyceride level in egg yolks among the studied fowls. In conclusion, although egg weight was significantly different among studied birds, eggs of guinea fowl, turkeys, and domestic chickens were similar in nutritional components.
\end{abstract}

Key words: Chemical composition, Domestic chicken, Egg Components, Guinea fowl, Turkey.

\section{INTRODUCTION}

Poultry such as chickens, quails, turkeys, pheasant, ostriches, ducks, and geese are domesticated birds as a source of animal protein with high nutritional value for human diets (Al-Obaidi et al., 2019). Production and consumption of table eggs have risen in the last years, global demand for table eggs will reach more than 50 million tons per year (Farrell, 2014; FAO, 2015; Farrell, 2015; Al-Shadeedi et al., 2019). Global egg production is increasing depending on global demand and is expected to increase in developing countries because it is easy to produce in a short time (USDA, 2016).

The egg has an optimal composition of essential amino acids and the favorable composition of essential fatty acids, a high percentage of polyunsaturated fatty acids and a favorable ratio of omega 6 to omega 3 fatty acids which has benefits for human health (Lass and Belluzzi, 2019). World demand and utilization of fowl eggs (raw egg consumption and for processed egg) are increased due to high nutritional value and multifunctional properties of eggs (Stadelman and Cotterill, 1995; Pingel, 2009; Al-Obaidi and Al-Shadeedi, 2016; Al-Shadeedi et al., 2019).
Since 2003, a new trend in table egg consumption was appeared through introducing a new poultry species for egg and meat production including ostrich, pheasants, turkey, and guinea fowl (Al-Obaidi and Al-Shadeedi, 2015; Al-Obaidi and Al-Shadeedi, 2017). Although chicken eggs are currently most commonly consumed by humans, the eggs from other birds are also used for daily consumption. For example, Japanese quail eggs are gaining popularity in Europe and America, and ostrich eggs in South Africa (Horanczuk et al., 2008).

Turkey (Meleagris gallopavo), belonging to the family Phasianidae, has good production performance and is reared in many countries of the world (Igenbayev et al., 2019). Guinea fowl (Numida meleagris) belongs to the Numididae family within the Galliformes order (Christopher, 2005). The peak of egg production of guinea fowl outdoor raised occurs in the rainy season (Konlan et al., 2011).

Poultry egg widely diverges in shape, volume, weight and amount of yolk and albumen material due to genetic factors (species, breed, and strain) and environmental factors (nutrition, disease and season) (Romanoff and Romanoff, 1949; Stadelman and Cotterill, 
1995; Konlan et al., 2011). Al-Obaidi and Al-Shadeedi (2015) found significant differences in the components of eggs from ostrich, emu, and domestic chicken. Although, ostrich and emu eggs are so similar to chicken eggs in the chemical composition. The aim of this study was to determine the weight, chemical composition and lipid profile of eggs from guinea fowl, turkey, and indigenous chicken outdoor reared in Baghdad.

\section{MATERIALS AND METHODS}

\section{Ethical approval}

This study was in accordance with guidelines for the care and handling of animals described by the Iraq Association of Genetic and Environmental Resources Conservation (AGERC-Iraq) Committee, Ministry of Higher Education and Scientific Research, Iraq.

\section{Birds}

Guineafowl (Numida meleagris), turkey (Meleagris gallopavo) and indigenous chicken strain (Barred plumage), were used in this study. These fowls were outdoor reared in traditional farms in Baghdad city, Iraq from January 20 to December 7, 2019.

\section{Fowl nutrition}

All birds were fed in the morning with $50 \mathrm{~g} /$ bird/day concentrated ration (Table 1). Also, birds had access to the outdoors and fed with grass.

Table 1. Proximate analysis and percentage composition of the diet used for feeding birds.

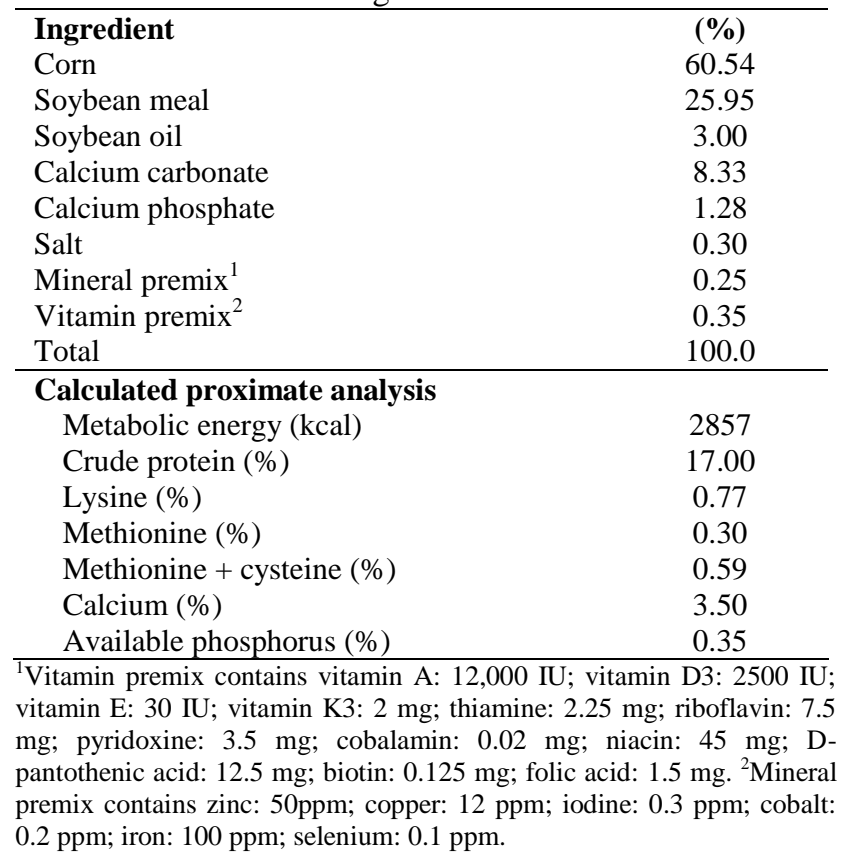

\section{Egg collection}

A total of 166 eggs of some native fowls, 32 eggs of guinea fowl, 44 eggs of turkey and 90 eggs of indigenous chicken freshly laid were collected.

\section{Egg components}

The percentage of egg components (yolk, albumen, and eggshell) was determined according to Stadelman and Cotterill (1995) as described by Al-Obaidi (2010). All eggs were weighted using a very sensitive digital balance (Sartorius, USA). Eggs were broken, the yolk and the albumen were separated and each weighted. Then, the percentage of each component was determined using the following equation:

$$
\text { Egg component }(\%)=\frac{\text { Egg component weight }(\mathrm{g})}{\text { Total egg weight }(\mathrm{g})} \times 100
$$

\section{Chemical analyses}

Protein and lipid composition were determined in albumen and yolk according to AOAC (1980). All measurements were performed in triplicate. Ash content was determined by thermal decomposition of the samples in a muffle furnace oven at $600{ }^{\circ} \mathrm{C}$ for 6 hours. Lipid content determination was conducted on yolk samples using the solvents of chloroform and methanol (1:1). The mixture of yolk sample and solvents were mixed for 20 min using a magnetic stirrer, then the weight of extracted lipid in each sample was recorded and its percentage was calculated. The semi-micro Kjeldahl method was used for the determination of nitrogen and the obtained values multiplied by 6.25 to calculate protein percentage.

Cholesterol was determined calorimetrically using ethanol extraction and ferric chloride-sulfuric acid detergent according to the method described by Al-Obaidi (1999). Low-Density Lipoprotein (LDL) and HighDensity Lipoprotein (HDL) were determined using EnzyChrom HDL and LDL Assay Kit (BioAssay Systems, USA). Triglycerides were eluted from yolk lipid using benzene and determined by silica gel column according to the methods described by AOAC (1980).

\section{Statistical analysis}

Data were analyzed using the general linear model procedure in SAS software (SAS Institute, USA). Means were compared by Duncan's multiple range test at 5\% probability level (Steel and Torrie, 1980). 


\section{RESULTS}

The results indicated significant differences $(\mathrm{p}<0.05)$ in egg weight among studied fowls. Guinea fowl had an average egg weight of $83.15 \mathrm{~g}$ compared to 92.41 and $61.28 \mathrm{~g}$ for turkey and indigenous chicken, respectively. There were no significant differences in the percentage of egg components among studied fowls, as shown in table 2. Also, the chemical composition of edible portions of eggs was not significantly different among studied birds (Table 3).
The lipid profile of egg yolk of studied birds is presented in table 4 . There were significant differences $(\mathrm{p}<0.05)$ in cholesterol and LDL levels, which were high in guinea fowl (26 and $48 \mathrm{mg} / \mathrm{g}$, respectively) and turkey (23 and $46 \mathrm{mg} / \mathrm{g}$, respectively) compared to native chicken (17 and $32 \mathrm{mg} / \mathrm{g}$, respectively); whereas native chicken had high values of HDL ( $85 \mathrm{mg} / \mathrm{g}$ ) compared to guinea fowl and turkey (73 and $70 \mathrm{mg} / \mathrm{g}$, respectively). No significant differences were found in triglyceride levels among the studied birds.

Table 2. Egg weight and percentage of egg components of guinea fowl, turkey, and domestic chicken reared outdoor in Baghdad, Iraq

\begin{tabular}{lcccc}
\hline Bird species & Egg weight $(\mathbf{g})$ & Eggshell $(\%)$ & Yolk $(\%)$ & Albumen $(\%)$ \\
\hline Guinea fowl & $83.15 \pm 0.72^{\mathrm{b}}$ & $10.75 \pm 0.30$ & $31.49 \pm 0.52$ & $57.76 \pm 0.72$ \\
Turkey & $92.41 \pm 0.78^{\mathrm{a}}$ & $10.61 \pm 0.28$ & $31.43 \pm 0.46$ & $57.96 \pm 0.65$ \\
Domestic chicken & $61.28 \pm 0.62^{\mathrm{c}}$ & $10.35 \pm 0.24$ & $31.57 \pm 0.39$ & $58.08 \pm 0.70$ \\
\hline
\end{tabular}

Data are express as mean \pm SE. Different superscript letters in a column indicate significant difference $(\mathrm{p}<0.05)$.

Table 3. Chemical composition of eggs of guinea fowl, turkey and domestic chicken reared outdoor in Baghdad, Iraq

\begin{tabular}{llccc}
\hline & Fowl species & Protein (\%) & Lipids (\%) & Ash (\%) \\
\hline \multirow{4}{*}{ Yolk } & Guinea fowl & $17.44 \pm 0.38$ & $32.53 \pm 1.12$ & $1.16 \pm 0.10$ \\
& Turkey & $17.52 \pm 0.41$ & $32.50 \pm 1.16$ & $1.15 \pm 0.10$ \\
& Domestic chicken & $17.48 \pm 0.39$ & $32.38 \pm 1.13$ & $1.16 \pm 0.11$ \\
Albumen & NS & NS & $1.10 \pm 0.10$ \\
& Significance & $11.66 \pm 0.21$ & - & $1.11 \pm 0.10$ \\
& Guinea fowl & $11.75 \pm 0.24$ & - & $1.11 \pm 0.10$ \\
& Turkey & $11.69 \pm 0.20$ & NS & NS \\
\hline
\end{tabular}

Data are express as mean \pm SE. NS: non-significant $(\mathrm{p}>0.05)$

Table 4. Lipid profile of egg yolk of guinea fowl, turkey, and domestic chicken reared outdoor in Baghdad, Iraq

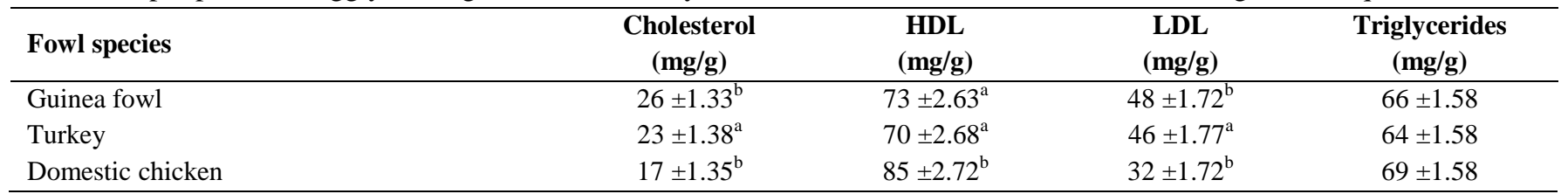

Data are express as mean \pm SE. different superscript letters in a column indicate significant difference $(\mathrm{p}<0.05)$.

\section{DISCUSSION}

Outdoor rearing of fowls offer many benefits to the sustainable farm, in addition to supplying eggs and/or meat, it enhances soil fertility and control weeds and insects (Bare and Ziegler-Ulsh, 2012; Al-Obaidi and AlShadeedi, 2018).

In Iraq, many birds flocks such as guinea fowl, turkey, and domestic chickens are outdoor reared, freerange or semi free-range, and may grow in low levels of nutrition and poor environmental condition during summer and winter. These variable conditions may affect components and chemical composition of eggs (Al-Obaidi, 2017; Al-Shadeedi et al., 2019). Native studies revealed that significant species differences in blood serum enzyme activity during the year, which will affect egg size and components (Al-Obaidi and Al-Shadeedi, 2014). Egg weight is an expression of size, that is mainly influenced by fowl body size, evolutionary status, climate condition, and the amount of available food. Also, egg size differs among different species and between individuals within the same species (Stadelman and Cotterill, 1995; Downing and Taylor, 2010). The present study is in agreement with 
Al-Obaidi and Al-Shadeedi (2014), Romero and RemageHealey (2000) and Kordonowy et al. (2017) that reported the egg weight and chemical composition differ between fowl species.

Fowl egg is one of the most complex and highly differentiated reproductive cells, which varies in size and shape depending on the type of species, breed and strain of birds (Romanoff and Romanoff, 1949; Stadelman and Cotterill, 1995; Al-Obaidi and Al-Shadeedi, 2014, 2016). Similarly, the current study indicated that egg of guinea fowl, turkey and chicken differed in size and weight.

Fowl egg consists of approximately 10\% shell, 58\% white and 32\% yolk (Stadelman and Cotterill, 1995; Matt et al., 2009; Al-Obaidi et al., 2019). The results obtained in the present study were similar to the mentioned values.

Egg white is a viscous colorless liquid consists of water $(88 \%)$, protein $(10-12 \%)$ and some minerals. The amount of lipid in the egg white is trace $(0.02 \%)$ compared with the amount present in the yolk. The yolk comprises $48 \%$ water, $15-17 \%$ protein, $32-34 \%$ fat, and some minerals and vitamins. Yolk lipid content is composed of triacylglycerols (63.3\%), phospholipids $(29.7 \%)$ and total cholesterol (5.2\%) (Stadelman and Cotterill, 1995; Marshall, 1960). The findings obtained in the current study are in agreement with the aforementioned reports. Cholesterol is the principal sterol synthesized by all kinds of animals and is important for cellular metabolism, cell membrane integrity, cellular proliferation, and steroid hormones synthesis (Brown, 2007). The high content of cholesterol in an egg is necessary to support the growth of the embryo. The high content of lipid fractions including cholesterol and LDL in guinea fowl and turkey eggs may be related to genetic variations between these birds compared to domestic chickens (Downing and Taylor, 2010; Farell, 2015; Al-Obaidi and Al-Shadeedi, 2016; AlShadeedi et al., 2019).

\section{CONCLUSION}

In conclusion, although egg weight in guinea fowl, turkeys, and native chickens was significantly different, nutritional components of eggs were similar among different birds.

\section{DECLARATIONS}

\section{Acknowledgments}

The author acknowledges and appreciated to Market Research and Consumer Protection Center, University of Baghdad and also to prof. Faris A. Al-Obaidi (Ph.D.), Iraq
Natural History Research Center \& Museum, University of Baghdad, Baghdad, Iraq for cooperation in the methods of egg chemical composition.

\section{Competing interests}

The author declared that she has no competing interests.

\section{REFERENCES}

Al-Obaidi FA (1999). Evaluation of quality and chemical composition of Japanese quail egg. Ph.D. Thesis, College of Agriculture, University of Baghdad.

Al-Obaidi FA (2010). Egg morphology characteristics and components of collared dove (Streptopelia decaocto) in Baghdad. 11 ${ }^{\text {th }}$ Scientific Symposium of Arab Scientific Heritage Revival Research Center, University of Baghdad, October $27^{\text {th }}$, 2010: 219-222.

Al-Obaidi FA (2017). Effect of summer and winter seasons on outdoor rearing of blood enzymes of some native chicken strains. Journal of Genetic and Environmental Resources Conservation, 5(1):55-58. Available at: http://www.gercj.com/index.php/gercj/home

Al-Obaidi FA and Al-Shadeedi ShMJ (2014). Seasonal variation in egg phenotype and chemical composition of collard dove (Streptopelia decaocto) in Baghdad. Journal of Genetic and Environmental Resources Conservation, 2(1): 69-73. Available at: http://www.gercj.com/index.php/gercj/home

Al-Obaidi FA and Al-Shadeedi ShMJ (2015). Comparison study of egg morphology, component and chemical composition of ostrich, emu and native chickens. Journal of Genetic and Environmental Resources Conservation, 3(2): 132-137. Available at: http://www.gercj.com/index.php/gercj/home

Al-Obaidi FA and Al-Shadeedi ShMJ (2016). Comparison study of egg morphology, component and chemical composition of Mallard duck and domestic Peking duck. Journal of Bio Innovation, 5(4): 555-562. Available at: https://www.jbino.com/index.htm

Al-Obaidi FA and Al-Shadeedi ShMJ (2017). Comparison some native fowls (chicken, mallard ducks quail and turkey) in components and chemical composition of the eggs in Iraq. Al-Anbar Journal of Veterinary Sciences, 10(1): 65-69. Available https://www.iasj.net/iasj?func=issues\&jId=146\&uiLanguag $\underline{\mathrm{e}=\mathrm{en}}$

Al-Obaidi FA and Al-Shadeedi ShMJ (2018). Effect of summer and winter seasons on egg abnormalities of outdoor rearing some native chicken strains. Journal of Biodiversity and Environmental Sciences (JBES) 12: 220-225. Available at: https://innspub.net/journal/journal-of-biodiversity-andenvironmental-sciences-jbes/

Al-Obaidi FA, Al-Shadeedi ShMJ and Al-Dalawi RH (2019). Table Egg and Designer Egg. $1^{\text {st }}$ Edition, LAP LAMBERT Academic Publishing, ISBN-10: 3659890421; EAN: 9783659890420, Available at: https://www.lappublishing.com/ 
Al-Shadeedi ShMJ, Al-Obaidi FA and Al-Dalawi RH (2019). Breeding and Management of Ducks and Geese. $1^{\text {st }}$ Edition, (in Arabic). Noor Publishing, ISBN-10: 6200068372; EAN: 9786200068378

Association of Official Analytical Chemists (AOAC) (1980). Official Methods of Analysis. $13^{\text {th }}$ Edition, Washington, DC, USA.

Bare M and Ziegler-Ulsh C (2012). Establishing a small-scale, sustainable, pastured poultry operation. Rodale Institute. Available at: https://rodaleinstitute.org/establishing-asmall-scale-sustainable-pastured-poultry-operation/

Brown AJ (2007). Cholesterol, statins and cancer. Clinical Experimental Pharmacology and Physiology, 34: 135-141. DOI: https://doi.org/10.1111/j.1440-1681.2007.04565.x

Downing JA and Taylor W (2010). The effect of strain and season on the performance of commercial ducks under Australian conditions. Proceedings of the Australian Poultry Science Symposium, 10: 182-185. Available at: https://az659834.vo.msecnd.net/eventsairaueprod/productio n-usyd-public/1330f0d28dc54ef39afea020d58a4da9

Farrell DJ (2014). Small-scale duck production: the way ahead. Journal of Animal Husbandry Science and Technology, 30(8): 73-80. Available at: http://scholarsinsight.org/journals/index.php?title=journalof-animal-husbandry-science-and-technology

Farrell D (2015). Recent advances in the production, management and nutrition of intensively-farmed domestic ducks. The Poultry Site - Poultry News, Health, Welfare, Diseases, Markets and Economics, England. Available at: https://thepoultrysite.com/

FAO (2015). Statistical pocket book, world food agriculture. Food and Agriculture Organization of the United Nations, Rome.

Horanczuk JO, Tomasik C and Cooper RG (2008). Ostrich farming in Poland - its history and current situation after accession to the European Union. Avian Poultry and Biological Review, 1: 65-71. DOI: https://doi.org/10.3184/175815508X360470

Igenbayev A, Nurgazezova A, Okuskhanova E, Rebezov Y, Kassymov S, Nurymkhan G, Tazeddinova D, Mironova I and Rebezov M (2019). Fatty acid composition of turkey meat. Journal of Worlds Poultry Research, 9(2): 78-81. DOI: https://dx.doi.org/10.36380/jwpr.2019.9

Konlan SP, Avornyo FK, Karbo N and Sulleyman A (2011). Increasing guinea fowl eggs availability and hatchability in the dry season. Journal of Worlds Poultry Research, 1(1): 1-3. Available at: http://jwpr.scienceline.com/index.php?option=com_content\&view=article\&id $=4 \&$ Itemid $=9$

Kordonowy L, Lombardo KD, Green HL, Dawson MD, Bolton EA, LaCourse S and MacManes MD (2017). Physiological and biochemical changes associated with acute experimental dehydration in the desert adapted mouse, Peromyscus Eremicus. Physiological Reproduction, 5(6): 22. DOI: https://doi.org/10.14814/phy2.13218

Lass A and Belluzzi A (2019). Omega-3 polyunsaturated fatty acids and IVF treatment. Reproductive Biomedicine Online (RBMO), $\quad 38(1)$ : $\quad$ 95-99. https://doi.org/10.1016/j.rbmo.2018.10.008

Marshall AJ (1960). Biology and Comparative Physiology of Birds, Volume 2. Academic Press, New York and London.

Matt D, Veromann E and Luik A (2009). Effect of housing systems on biochemical composition of chicken eggs. AgronomResearchch, 7(2): 662-667. Available at: https://agronomy.emu.ee/

Pingel H (2009). Waterfowl production for food security. IV World Waterfowl Conference, 11-13 Novembr, 2009, Thrissur, India. Available at: http://www.waterfowl2009.vetcos.com/proceedings\%20\%20IV\%20WWC\%20-\%20Kerala,\%20India.pdf

Romanoff AL and Romanoff A (1949). The Avian Egg. John Wiley and Sons Co., New York, USA.

Romero LM and Remage-Healey L (2000). Daily and seasonal variation in response to stress in captive starlings (Sturnus vulgaris): corticosterone. General and Comparative Endocrinology, 119(1): 52-59. DOI: https://doi.org/10.1006/gcen.2000.7491.

SAS Institute (2001). SAS/STAT User's Guide for Personal Computer. Release 6.12 SAS Institute, INC., Cary, N.C., USA.

Stadelman WJ and Cotterill OJ (1995). Egg Science and Technology. $4^{\text {th }}$ Edition. Food Products Press . An Imprint of the Haworth Press. INC. New York. London, UK

Steel RG and Torrie JH (1980). Principle and Procedures of Statistics. $2^{\text {nd }}$ Edition. McGrow-Hill Book Co., Inc., New York, USA.

USDA (2016). International Egg and Poultry: FAO's Food Outlook Report. Available at: http://www.thepoultrysite.com/reports/?id=4277 